\title{
Determinants of Financing Pattern and Access to Formal -Informal Credit: The Case of Small and Medium Sized Enterprises in Viet Nam
}

\author{
Nhung Nguyen (Corresponding author) \\ Faculty of Commerce, Lincoln University \\ PO Box 85084, Christchurch, New Zealand \\ Tel: 64-22-100-4694Ｅ-mail:nhung.nguyen@lincolnuni.ac.nz \\ Nhung Luu \\ Faculty of Economics and Management, Minho University, \\ Largo do Paco, 4704-553, Braga, Portugal \\ Tel: 351-25-360-1100 E-mail: nhung.luu@aiesec.net
}

$\begin{array}{lc}\text { Received: February 15, } 2013 \quad \text { Accepted: March 24, } 2013 \quad \text { Published: April 5, } 2013 \\ \text { doi:10.5296/jmr.v5i2.3266 } & \text { URL: http://dx.doi.org/10.5296/jmr.v5i2.3266 }\end{array}$

\begin{abstract}
We investigate factors from firm side that determine their financing pattern for new investment projects and their decision to choose formal, informal credit, or both. For financing pattern of new investment project, we use Random-effect model while Unordered-Multinomial Logistic is used to estimate probability of choosing any of four choices to access to finance, say, formal credit, informal credit, both of them, or none of them. Our analysis is based on a panel of around 2200 small and medium sized enterprises with 7900 observations extracted from the "Survey of small and medium scale manufacturing enterprises in Viet Nam" in 2005, 2007, and 2009.
\end{abstract}

Keywords: Small and medium sized enterprises, Access to finance, Formal credit, Informal credit, Viet Nam 


\section{Introduction and Research Objectives}

Small and medium sized enterprises (SMEs) are perceived to be the backbone of any economies worldwide by their main contributions to national income, job creation, poverty alleviation, export promotion, etc. For instance, recent annual report from European commission(EC, 2011) showed that, despite the fragile economic environment, SMEs have retained the key-led growth of the European economy, accounting for more than $98 \%$ of all enterprises, generating $67 \%$ of total employment and $58 \%$ of gross value added in 2012 . Data and reports from SMEs sub-group also point out that SMEs in developing countries also play crucial role with their contribution to employment of $45 \%$ and to annual GDP of $33 \%$.

In Viet Nam, since the promulgation of the Enterprise Law, with their rapid development in terms of both quantity and quality, SMEs have made considerable contributions to the country's economic development. SMEs represent $99 \%$ of the number of businesses, as well as $77 \%$ of the workforce and produce around $40 \%$ of annually GDP (Runckel, 2011). In addition, during 2001-2007, this sector made up for 24\% of total industrial production value and approximately 50\% of total export value. In 2008, the amount of capital investment of the sector was 220.5 thousand billion VND, equivalent to $31 \%$ total country investment (MPI, 2010). In Table 1, we present some performance indicators of SMEs in Viet Nam.

However, despite of their major contributions, SMEs are facing a number of obstacles to develop; and financing is an important one among them. SMEs are generally considered riskier than large firms because they have lower survival rate, larger variance of profitability and growth (OECD, 1998). As a result, SMEs often suffer from credit rationing or higher interest rate. And financing constraints indeed limit their growth (Beck \& Demirguc-Kunt, 2006). In least developed countries, such as Sub-Sahara Africa, access to finance is the most important obstacle to SME entry and growth investment(Fjose, Grünfeld, \& Green, 2010). In Viet Nam, according to a recent research conducted by VCCI, 75\% SMEs would like to seek bank loans but only about $30 \%$ of them succeeded. It is because not only is the lending procedure too much complicated but the interest rate charging on SMEs is also too high (for example, interest rate charged for small enterprises at VIB bank on 20 November 2012 was $16.29 \%$ per year $^{1}$ )

The above context emerges the question of what factors determine the accessibility to finance of SMEs in Viet Nam. When searching for the answer, several reasons have been noted to our review. Nevertheless, previous studies have either dealt with only some specific factors such as networking (Le \& Nguyen, 2009; Malesky \& Taussig, 2009)or based on small sample size(Le, Venkatesh, \& Nguyen, 2006; Thanh, Cuong, Dung, \& Chieu, 2011). Moreover, these articles mainly focused on accessing bank credit while neglecting informal sources as well as making no explanation why some firms access two types of credit. Therefore, our study attempts to accomplish the following objectives:

\footnotetext{
${ }^{1}$ Retrieved from VIB bank website on 19 Jan 2013 at http://vib.com.vn/1775-truy-cap-nhanh/2275-lai-suat-cho-vay.aspx
} 
- To determine financing pattern of SMEs; specifically, when investing in new projects, how firms decide the proportion of using their own capital, bank capital or other sources of capital.

- To investigate factors that influence access to finance, particularly, whether to use formal capital, informal capital, both of them or none of them.

\section{Literature Review}

Previous literature worldwide has suggested that factors determining access to finance of firms can be divided into four main groups: Owner's characteristics, firm's characteristics, firm's location, and ownership types (Akoten, Sawada, \& Otsuka, 2006; Beck, 2007; Beck \& Demirguc-Kunt, 2006; Coleman, 2004; Le et al., 2006; Rand, 2007; Thanh et al., 2011). Furthermore, many scholars have also emphasized the role of networking, particularly in the context of firms in developing countries (Le \& Nguyen, 2009; Malesky \& Taussig, 2009). Therefore, in the following parts, we will go through these determinants.

\subsection{Characteristics of Owners}

Owners/managers ${ }^{2}$ characteristics, which include their age, education, professional experience, management skills, etc., have been consistently proposed to influence firms' access to credit. Concerning educational background, Kasseeah \& Thoplan (2012) suggested that the level of education of owner, which is measured by primary, secondary and tertiary education, do contribute positively to the performance of SMEs. SMEs with more highly educated owners seem to perform better even after controlling for age, experience and employment level. Higher education brings business owners to a better position to understand the requirements for operating a business and may help them manage various aspects of the business. Education associated with experience also equips managers to better prepare and present a loan application in the form that a lender wants to see (Coleman, 2004). Empirically, in a study of 4400 small firms, Bates (1990) found that owners with four or five years of college/university could access to bank capital more easily but there was no evidence that high education level improve access to non-bank capital.

The impact of education on access to finance for SMEs in Viet Nam, however, seems very mixed. On the one hand, Thanh et al. (2011) found that firm owner's experience significantly reduce the probability of bank loan rejected. On the other hand, Le, Venkatesh, \& Nguyen(2006)argued that owner's education is negatively correlated with bank loan. According to Rand (2007), there are likely negative correlations between being high or medium skilled and accessing credit, reflecting that owners with higher skill levels have lower demand for debts and finance themselves by internal funds or that better educated and experienced owners are more likely to know when their application will be rejected and therefore refrain from applying.

In terms of gender, Baydas, Bahloul, \& Adams(1995) and Tsai(2004)both suggested that less educated and "finance literate" women participate more in the informal financial transactions

\footnotetext{
${ }^{2}$ In this paper, we do not distinguish the term owner and manager. In other words, owner and manager will be used as inter-changeable words.
} 
compared to men. In contrast, Yaldiz (2011), argued that to establish and conduct a business in men's world, business women can be considered as better educated, more talented compared to other business men. As a result, he empirically proved that women are likely to have more ability to access formal credit.

Regarding to owner's age, Yaldiz et al.(2010) proposed the positive correlation between owner's age and working experience, which likely helps reduce the firm's financing obstacles. However, Nakano \& Nguyen(2011) argued that the older the leaders get, the more risk-averse and less energetic at work they are. As a result, they seem to prefer use more formally external loans or their own asset rather than approaching informal debts.

In brief, owner's characteristics might have very mixed impact on accessibility of formal and/or informal capital and the result seems to vary across countries.

\subsection{Characteristics of Firms}

Various researches have pointed out that credit accessibility varies among firms according to firm-specific characteristic, and its characteristic, in return, determines the best suited way for firms to approach credit. In particular, size of firms which is one of the most reliable predictor of firms' financing obstacles also explains to firms' differentiate fund choices ((Beck, 2007; Beck, Demirgüç-Kunt, Laeven, \& Maksimovic, 2006; Bernanke, Gertler, \& Gilchrist, 1994; Devereux \& Schiantarelli, 1990). Beck and Levine (2004) suggested that small firms have to finance a larger share of investment with informal sources, such as moneylenders or family and friends or heavily depend on short-term bank loans; whereas larger firms facilitate their investment by a greater share of formal external sources like equity, bank finance. Technically, this finding matches the theoretical models that used fixed transaction costs and information asymmetries and the resulting agency problems as basis for financial market frictions ${ }^{3}$. Economically, large firms, which face less constraint in credit are likely to access many alternative fund sources. In the meanwhile, small firms with their small size give a signal of relatively higher credit risk so that the banks, which are risk-averse, has less incentive to lend them money (Black, 2012). As a result, they are likely to depend more on informal sources. While firm size used to be measured by the number of employees and the annual turnover thresholds (EC, 2005), Coleman's report (2002)also suggested that a firm's profit could be introduced as a useful proxy.

Age of a firm has also been reported to determine the choice of credit finance in many studies. Gertler (1988) stated that information asymmetries are likely to be especially large for young and newly-established firms, because creditors have not had enough time to monitor such firms and because such firms have not had enough time to build long-term relationships with suppliers of finance. As a result, young enterprises, especially the start-ups, are likely to seek finance from informal sources, whereas the older have more advantage in searching for bank debts or equity. This result was also empirically proved by many authors, such as Akoten, et al.,(2006), Oliner \& Rudebusch(1992) and Beck, et al., (2006). However, Rand (2007) found a negative relation between age and holding debts. His argument was that old firms are often

\footnotetext{
${ }^{3}$ See Levine (2005) for an overview
} 
more settled and less likely to engage in activities that risky and requiring a huge amount of capital investment, so they may seek formal sources of credit less. Besides, with the support from pecking order theory proposed by Myers(1984), old firms are more likely to finance themselves through their internal credit (Le, 2012).

Last but not least, it is also claimed that in less developed countries where institutional system is not well-developed, collateral and guarantees, which are represented by the ratio of tangible asset in total asset, remain one of 3 main factors leading to banks' lending decision (Uchida, 2011). While Viet Nam's institutional system is far from developed, the bank system is less competitive and possession of property rights still have a large positive impact on ease of credit, firms that lack collateral assets account for a major proportion of rejected loan requesters (Thanh et al., 2011).

\subsection{Firm's Location}

Beck (2007) noted there is a broad variation of firms' financing obstacles among countries after controlling for cross-country difference in GDP per capita, suggesting that geography or, more specifically, firms' location is likely to involve in credit constraint, and therefore is an explanatory factor for firms' credit determination. Yaldiz(2011)empirically showed that firms located in smaller cities rely more on informal credit compared to firms in bigger cities. Gine(2011) documented that the transaction cost to evaluate the creditworthiness of a firm is likely high in rural areas, hence bank are less willing to lend firms in the rural or long-distance areas. On the other hand, firms located in the urban areas or near a commercial bank may access bank loans likely more easily since it is convenient for a bank to monitor and obtain "soft" information that allow it to give an decision on loan requests (Petersen \& Rajan, 2002)

\subsection{Ownership Types}

Literature has also revealed the diverse financing pattern across firm categories. Generally speaking, government-owned firms, which suffer less financing obstacles than others, can access to formal debts more easily since they receive direct budgetary support from the government and favorable treatment from government-owned financial institutions (Harrison, Love, \& McMillan, 2004; Laeven, 2003).

\subsection{The Role of Networking}

This last determinant seems to have a great voice over financing pattern of SMEs, particularly in developing countries where financial system is under-developed. According to Shane \& Cable (2002), networks can be used to reduce information symmetry in creditor/debtor relationship. At large, networking and relationships substitute for the lack of effective market institution, and can be an effective way for firms to access external credit, including bank loans. Networks and relationships increase a firm's legitimacy, which in turn positively influence the firm's access to credit. In addition, Safavian \& Wimpey (2007) and Straub (2005) agreed that networks are also important for firms which largely rely on informal sources of credit. Lenders rely primarily on "soft" information gathered through contact over time with the SME, observing its profitability 
performance and previous loan payments history to judge the creditworthiness of the firms and to price the loans. This result is consistent with Rand (2007) finding that firms which have borrowed from the creditor before and have built up some kind of business relationship are faced with significantly lower cost of capitals. Further, Bougheas, Mizen, \&Yalcin(2006) suggested that network is a dominant determinant that helps firms less financially constrained, since relationships with the lenders makes a firm easier to access credit, even when it is weak on other criteria. For the case of Viet Nam, Le \& Nguyen (2009) found that official network, the relationship with government officials or bankers, are significantly and positively associated with the possibility of acquiring bank loans; however, it doesn't have enough power to influence the actual amount of bank lending. In another approach, Le et al.(2006) also added that networking for firms in the first stage more effectively help them access credit than that of later growth stage firms. They argued that through networking, especially with government officials, firm legitimacy increases in the eye of aid donors and government support programs, hence raising the accessibility to the less expensive sources of financing. On the other hand, they also suggested that social networks, especially network with members of social organization or clubs, significantly increase the ability of approaching informal credits. Malesky \& Taussig (2009) further added that bank credit accessibility is likely easier for Viet Nam's rural companies, but more difficult to firms in more competitive and better governed urban environments. They explained that the result comes from the fact that Viet Nam state-owned commercial banks' lending purpose is in favor of rural enterprises to improve national welfare.

\section{Data and models}

\subsection{Financing Pattern for New Investment Project}

We first examine the determinants of financing pattern for new investment project of SMEs. The following model is to be tested:

$$
\operatorname{SOURCE}_{i t}=\alpha_{0}+\beta_{1} \mathrm{OWNER}_{i t}+\beta_{2} \text { FIRM }_{i t}+\beta_{3} \text { REGION }_{i t}+\beta_{4} \text { NETWORK }_{i t}+\beta_{5} \mathrm{OWNERSHIP}_{i t}+v_{i t}
$$

In which:

$t$ is the time periods, which is 2005, 2007, and 2009

$S O U R C E_{i t}$ is the dependent variable representing sources of financing new investment project, namely using own capital, borrowing from bank, and using other sources. These sources are expressed as the percentage of total credit.

$O W N E R_{i}$ is a set of variable representing owner's/manager's characteristics, including: age, gender, ethnic, basic education level, professional education level and knowledge about Enterprise law and Tax law

$F I R M_{i}$ is a set of variable representing firm's characteristics, including: firm's age, firm's profit (proxy for firm's size), a dummy variable that equals to 1 if it is easy to access main roads and 0 otherwise, a dummy variable that equals to 1 if firm is located near a rail;a dummy variable that equals to 1 if firm export and 0 otherwise, one dummy variable for land 
ownership which equal to one if firm has certificate of land use right and 0 otherwise, a dummy variable that equals to 1 if firm has an accounting book and 0 otherwise.

REGION $_{i}$ variableis a set of dummy variables that take values of 1 if the enterprises are located in either Ha Noi, PhuTho, Ha Tay, HaiPhong, Nghe An, Quang Nam, KhanhHoa, Lam Dong, Hochiminh or Long An and take values of 0 if otherwise.

NETWORK $K_{i}$ variable includes number of bank officials the firm frequently contact with, number of business association memberships, and one dummy variable that equals to 1 if firm's owner/manager is a member of Communist party.

$v_{i t}$ is the error terms

\subsection{Determinants of Access to Finance}

In order to go deeper insight into the determinants of the choice of formal or informal credit access, we also run the multiple-logistic model in which we keep the same set of independent variables but the dependent variable becomes choices of credit access, say, formal credit, informal credit, both of them or none of them.

The firms' credit access is an unordered categorical variable which is denoted by choice $\mathrm{ijt}_{\mathrm{jt}}$ whereas index $\mathrm{i}$ identifies firms, $\mathrm{j}$ is the alternative within the choice set and $\mathrm{t}$ indicates the time firms made the choice. Since we fit the multinomial model with a series of choices, we let the default base category is choice ${ }_{\mathrm{ijt}}=1$, which represents for using owner's fund choice, and then we find the changes of choices over time by comparing each of the other alternatives in the category with the base choice. Formally, our estimation model can be displayed as follows:

$$
\log \left(\frac{\text { choice } \left._{i j t)}\right)}{\text { choice }_{i 1 t}}\right)=\alpha_{i j}+X_{i j t} \beta_{i j}+u_{j}, \text { where } \quad \mathrm{u}_{\mathrm{j}} \sim \operatorname{IID}\left(0, \sigma_{\mathrm{u}}{ }^{2}\right) \text { and } \mathrm{j} \neq 1
$$

$\mathrm{X}_{\mathrm{ijt}}$ is the same set of explanatory variables that is used in the previous model.

Therefore, the probability of making choice $\mathrm{j}$ conditional on observed characteristics $X_{i t}$ that vary between firms over time and unobserved individual effect $\alpha_{i}$ that are time constant has the following form:

$$
\mathrm{P}\left(\mathrm{j} \mid \mathrm{X}_{\mathrm{it}}, \alpha_{\mathrm{i}}\right)=\frac{\exp \left(X_{i t} \beta_{j}+\alpha_{i j}\right)}{\sum_{k=1}^{4} \exp \left(X_{i t} \beta_{k}+\alpha_{i k}\right)},
$$

where the unobserved heterogeneity ais identically and independently distributed over the firms with the mean a and variance-covariance matrix $\mathrm{W}$, denoted $\alpha \sim$ IID (a, W).

Finally, it is important to note that in both two equations (3.1) and (3.2), we use random effect (RE) model for estimation. We have reasons to do so when taking into account characteristics of our panel data and we also use Dubin-Wu-Hausman test to empirically confirm the appropriateness of $\mathrm{RE}^{4}$.

\footnotetext{
${ }^{4}$ Details of these tests are available upon request.
} 
Data used for our analysis was based on the Survey of small and medium scale manufacturing enterprises (SMEs) in Viet Nam which were conducted by ILSSA in the Ministry of Labour, Invalids and Social Affairs (MOLISA) and University of Copenhagen with funding from DANIDA in 1991, 1997, 2002, 2005, 2007, and 2009. Due to the inconsistency of the questionnaires before 2005, we only merged the dataset in 2005, 2007, and 2009. Our panel includes about 2200 firms and 7900 observations.

Table 2 summarizes and explains main variables used in our models.

Running pairwise correlation test to identify potential correlations between variables, we decide to omit etp_law, ownership1 and edu_bs4 variables from regression models because

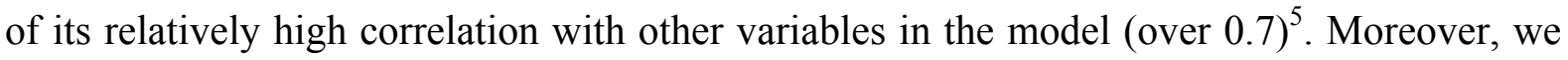
also decide not to introduce the interaction variables into the model due to the scope of the data. In particular, the growth stage is proposed to be subjectively measured by the judgment of firm's manager on its business condition (Le et al, 2006) or objectively measured by the current structure of the organization. These two sorts of information are not available in our dataset.

\section{Results and Discussion}

\subsection{Financing Pattern for New Investment Project}

Table 3 presents results of RE estimation for model 3.1. Interesting results are yielded from the model. First of all, owner's demographic characteristics (age, ethnic, and gender) seem not important in determining what sources of credit to finance new investment. Owner's education level, however, does. Keeping other things constant, we find that the owner who was an unskilled worker or elementary worker use less proportion of other sources financing than the one who was not. By contrary, the one who obtained college/university/post graduate used more proportion of other source finance and less own capital. Interestingly, the result is opposite when it comes to owner's knowledge about Tax law variable. The owner with better tax knowledge is more likely to use more bank capital to finance new investment, cetaris paribus. These results are opposite to Bates (1990),Coleman(2004), and Fatoki \& Odeyemi (2010) but very consistent with what have been found for the case of SMEs in Viet Nam by Le, Venkatesh, \& Nguyen (2006)and Rand (2007).

Regarding to firm's characteristics, as expected, firm's size is strongly correlated to sources of financing new investment. Larger firms seem to rely more on self-capital and bank capital and less on other sources. Having export activity significantly decreases the use of own capital to finance new investment and increases the use of other source's finance but is not statistically significant to the choice of bank finance. Similar effects to export variable are also seen with the variable of firm's accounting book availability. Firm's age and favorable locations nearby main road do not significantly determine borrowing structure. One result that is not expected is firms easily access to rail has lower proportion of borrowing from bank and higher proportion of borrowing from other sources. Lastly, having certificate of land right ownership does not make it easier to access bank's finance.

\footnotetext{
${ }^{5}$ We do not report pairwise correlation table here. It is available upon request.
} 
Network variables, which we predict to be strongly important in financing structure, yield expected results. Stronger network with bank officials remarkably increases the use of bank and other sources financing while reducing the proportion of using own capital. Our result strongly supports Malesky \& Taussig(2009). Being a member of business association, however, do not have statistically significant effect on accessing bank capital. Member of business association appears to be helpful for firm to access other sources of capital, which is understandable. Lastly, there is no different across all types of financing new investment whether the owner is a member of Communist Party or not.

Finally, the regional variables show interesting results. Firms in small provinces such as NgheAn rely mostly on their own capital rather than bank or other sources of credit which is reasonable as the availability of financial institutions is not widespread. In big cities like HaNoi, HaiPhong, HaTay, and Hochiminh, where financial institutions are everywhere, yet, firms also do not find it's easier to access bank loans. This result might reflect the ability of firms in big cities to raise capital on their own or within their extensive networks. Alternatively, more bank branches do not mean easier loan application evaluation. In addition, having more firms also means higher opportunity cost due to longer queue.

\subsection{Determinants of Access to Finance}

Table 4 presents the results of estimating the determinants of access to the informal, formal sources or both of them. The results suggest that borrowers from informal sources like friends and relatives seem to be young managers. The older they are, the more probability they can access to bank debts and/or equities. This finding is consistent with Rand (Rand, 2007), Akoten, Sawada, \& Otsuka (2006), and Johnson(2004). Young managers are likely to lack social capital than the older including leading experience, financing network, and accountability, etc. which in turn let the banks, which are risk-averse, are less willing to lend money. Hence, they have no alternatives but relying on their own assets or friends and relatives' capital. In the other hand, the results surprisingly mention that the length of time a firm operates doesn't help them out of financing constraints. Additionally, the more incumbent is a firm in the market, the less likely the firm access to both informal and formal credit. This finding gets support from Rand (2007) report saying that old firms are more settled and likely require fewer debts than the others.

The results also suggest that human capital of a firm's owners, which reflects in their basic and professional education, support the firms to seek finance, though most of these coefficients are not statistically significant. The higher education or more experienced managers may not only have larger social network but also make more wise and convincing loan applications. Moreover, the magnitude of the coefficients' value in formal source borrower group higher than the ones in both informal and formal group indicates that, under financing constraint, firms prefer to borrow money from banks or issue equity rather than asking for informal debts.

Not surprisingly the more productive firms' operation, the less financing obstacles they face. The finding shows that firms which obtain higher profit significantly have more ability to approach both formal and informal debts, whereas the firms got failure in doing business 
have no choice but leaning on informal credits or owners' assets. Besides, the findings tell that firms more or less face credit constraints no matter what sort of ownership they are. The significantly positive coefficients in the Multi-nominal logit model suggest that firms tend to solve their financing problem by wisely combining informal and formal borrowings. Due to the amount borrowing restriction of informal source and the difficulty of formal credit access, firms are less likely to satisfy their credit demand by being solely prone to bank loans, owner's capital or informal fund. In addition, the common positive correlation of private, partnership and limited liability companies with formal financing is consistent with the finding reported by Rand (2007) that these particular firms are of the highest demand for external funds. Last but not least, export firms are suggested to face less financing constraint than the other thanks to the supportive lending policies of the government in favor of exports. Even the results are not significant they show that these firms tend to borrow more from formally external funds like bank debts rather than seeking for informal credit.

Although collateral possession was suggested to be the crucial key to approach bank debts, the result herein suggests that this characteristic doesn't function well as expected. The magnitude of coefficient reveals that firms which have more valuable collateral, especially lands, are likely to approach more formal funds than informal ones; however, the asset doesn't help firms much in getting rid of financing constraint. Nevertheless, these results are not statistically significant.

While collateral does not matter, accounting book does. The result indicates that firms which have a standard account book are reported to have more probability in accessing formally external credits. This result also comes from the reduction of asymmetric information as well as judgment cost from formal creditors. In particular, account book is a reliable thing that banks can base on to assess firms' credit worthiness in terms of profitability, risks, productivity. This finding coincides with the previous reports from Allee \& Yohn(2009) and Uchida (2011).

Again, the network variable does help firms reduce their credit obstacles. On one hand, firms which have relationship with banks do help them less financing constrained than the others. As a result, they not only can access bank debts but also have more advantage to persuade informal creditors to give them loans. This finding can be explained by the fact that the network between creditors and borrowers, which may come from previous operations, owners' private contacts, etc., reduces the asymmetric information as well as the cost banks have to spend to judge firms' business productivity. On the other hand, the owner's social network which is also represented by his ethnic significantly helps increase credit accessibility. Interestingly the results tell us that managers belonging to majority ethnic group likely find more easily to seek finance more bank debts or equity as well as informal funds rather than ones coming from minority group, which is also consistent with the reports from Akoten, et al.(2006)

The firms' geography surprisingly reveals another story about firms' credit access. Again, our finding in the second model is very consistent to result from model of financing pattern. Firms which locate in the big cities like Hanoi, Ho Chi Minh or HaiPhong are used to be 
supposed to access more formal credits than the informal due to relatively lower transaction cost; however, the findings tells us that the reduction in transaction cost is likely not enough to offset the time consuming to queue up the borrower lines and access the credit so that these firms seem to be prone to borrow from informal funds. This result is also convinced by the fact that the informal lending market is more developed and is of complex operation than ones in the small cities. Besides, firms located in the areas which receive higher Provincial Competitiveness Index like Quang Nam, KhanhHoa, NgheAn significantly increase access to formal credits. This observation, however, is inconsistent with the finding suggested by Rand (2007) and Phuong (2012). These results are consistent with the ones proposed by Thanh et al(2011) about State-owned commercial banks (SOCB)'s lending targets in favor of rural enterprises.

\section{Implications and Conclusion}

This paper used the Survey of small and medium scale manufacturing enterprises in Viet Nam to determine the financing pattern for new investment project and their decision to seek formal, informal credit or both. By random effect model and multinomial logistic model, we expect to receive the consistent results from different approaches. After controlling for correlation, endogeneity, and model specification, these models both demonstrated interesting results about financing pattern and choice of capital of SMEs. Firstly, while types of ownership seems not important, having accounting book and the size of the firms do matter in the way that small firms are likely to have more constraint than the bigger ones. Secondly, networking, which includes official networking and social network, significantly increases SMEs' ability to access to bank and other source of capital. Thirdly, firms located in big cities like Hanoi, Ho Chi Minh or HaiPhong are less likely to access formal credit and tend to increase more proportion of debts coming from informal sources, which is converse to what people used to suppose. As a result, the advantages of locating in a better infrastructure like staying near the railway or main road doesn't help firms much to get out of their financing troubles. In contrast, firms in rural areas seem to use their own capital and access more the bank debts and less the informal ones. Lastly, firm's owner characteristics including age, ethnic, professional experience do significantly impact the ability to borrow from formal sources. Particularly, firms whose managers are older, from Kinh group and have higher professional experience tend to have higher probability to access formally external funds than the others.

Our findings provide an insight into the current supply -demand gap in the capital market in Viet Nam and also raise the needs of reconsidering current SMEs supporting programs. On one hand, the Government should enhance the firm evaluation system through standardizing the accounting and auditing system, orient firms and banks to use more credit guarantee funds rather than collateral or property for mortgage. On the other hand, Government should encourage firms' managers to improve their education background or skills by effectively organizing the leaders' training program, in which indirectly strengthen SME's capacity to prepare loan-financed project documentation in order to meet credit provider's requirements. Since there is a mismatch between capital demand and supply, the government could encourage firms and banks to create networks. Not only does this activity reduce the 
asymmetric information between firms and banks, but it also enhances inter-firm corporations for urgent or short-term credit needs. Moreover, even the SOCB's lending purpose is fruitful in terms of welfare, there still raises a need to reconsider the unproductive lending systems in big cities as firms and banks in urban areas are losing their advantages of lower transaction cost due to high competition to bank loans and the development of informal lending market. In this case, we think that a large part of informal lending system should be well administered and upgraded into an official one like inter-firms funds.

\section{References}

Akoten, J. E., Sawada, Y., \& Otsuka, K. (2006). The determinants of credit access and its impacts on micro and small enterprises: The case of garment producers in Kenya. Economic development and cultural change, 54(4), 927-944. http://dx.doi.org/10.1086/503585

Allee, K. D., \& Yohn, T. L. (2009). The demand for financial statements in an unregulated environment: An examination of the production and use of financial statements by privately held small businesses. The Accounting Review, 84(1), 1-25. http://dx.doi.org/10.2308/accr.2009.84.1.1

Bates, T. (1990). Entrepreneur human capital inputs and small business longevity. The review of Economics and Statistics, 551-559. http://dx.doi.org/10.2307/2109594

Baydas, M. M., Bahloul, Z., \& Adams, D. W. (1995). Informal finance in Egypt:"banks" within banks. World Development, 23(4), 651-661. http://dx.doi.org/10.1016/0305-750X(94)00150-W

Beck, T. (2007). Financing constraints of SMEs in developing countries: Evidence, determinants and solutions. The World Bank. Washington DC.

Beck, T., \& Demirguc-Kunt, A. (2006). Small and medium-size enterprises: Access to finance as a growth constraint. Journal of Banking \& Finance, 30(11), 2931-2943. http://dx.doi.org/10.1016/j.jbankfin.2006.05.009

Beck, T., Demirgüç-Kunt, A., Laeven, L., \& Maksimovic, V. (2006). The determinants of financing obstacles. Journal of International Money and Finance, 25(6), 932-952. http://dx.doi.org/10.1016/j.jimonfin.2006.07.005

Beck, T., Demirguc-Kunt, A., \& Levine, R. (2004). Law and firms' access to finance: National Bureau of Economic Research. http://dx.doi.org/10.1596/1813-9450-3194

Bernanke, B., Gertler, M., \& Gilchrist, S. (1994). The financial accelerator and the flight to quality: National Bureau of Economic Research.

Black, S. F., Amy;Guttman,Rochelle. (2012). The financial characteristics of small business. Small business finance roundtable, 25-32.

Bougheas, S., Mizen, P., \& Yalcin, C. (2006). Access to external finance: Theory and evidence on the impact of monetary policy and firm-specific characteristics. Journal of Banking \&amp; Finance, 30(1), 199-227. http://dx.doi.org/10.1016/j.jbankfin.2005.01.002 
Coleman, S. (2002). Small firm use of debt: An examination of the smallest firms. Journal of Entrepreneurial Finance 7(1), 51-76.

Coleman, S. (2004). The role of education and experience in small firm access to bank loans: Is there a link. Journal of Business and Entrepreneurship, 16(1), 1-16.

Devereux, M., \& Schiantarelli, F. (1990). Investment, financial factors, and cash flow: evidence from UK panel data. In Asymmetric information, corporate finance, and investment (pp. 279-306): University of Chicago Press, 1990.

EC. (2005). The new SMEs definition: Userguide and model declaration: European Commission. Retrieved from

http://ec.europa.eu/enterprise/policies/sme/files/sme_definition/sme_user_guide_en.pdf

EC. (2011). Seventh progress report on SMEs participation in the 7th R\&D Framework program. Brussels: European Commission. Retrieved from http://ec.europa.eu/research/sme-techweb/pdf/smes-in-fp7-spring-2011_full-rep_en.pdf

Fatoki, O., \& Odeyemi, A. (2010). Which New Small and Medium Enterprises in South Africa Have Access to Bank Credit? International Journal of Business and Management, 5(10), P128.

Fjose, S., Grünfeld, L. A., \& Green, C. (2010). SMEs and growth in Sub-Saharan Africa: MENON Business Economics.

Gertler, M. (1988). Financial structure and aggregate economic activity: an overview: National Bureau of Economic Research Cambridge, Mass., USA

Gine, X. (2011). Access to capital in rural Thailand: an estimated model of formal vs. informal credit. Journal of Development Economics, 96(1), 16-29. http://dx.doi.org/10.1016/j.jdeveco.2010.07.001

Harrison, A. E., Love, I., \& McMillan, M. S. (2004). Global capital flows and financing constraints. Journal of Development Economics, 75(1), 269-301. http://dx.doi.org/10.1016/j.jdeveco.2003.10.002

Johnson, C. A. (2004). Choosing people: the role of social capital in information seeking behaviour. Information Research, 10(1), 10-11.

http://dx.doi.org/10.1016/j.jdeveco.2003.10.002

Kasseeah, H., \& Thoplan, R. (2012). Access to Financing in a Small Island Economy: Evidence From Mauritius. Journal of African Business, 13(3), 221-231. http://dx.doi.org/10.1080/15228916.2012.727753

Laeven, L. (2003). Does financial liberalization reduce financing constraints? Financial Management, 5-34. http://dx.doi.org/10.2307/3666202

Le. (2012). What Determines the Access to Credit by SMEs? A Case Study in Viet Nam. Journal of management research, 4(4). doi:http://dx.doi.org/10.5296/jmr.v4i4.1838 
Le, \& Nguyen, T. V. (2009). The Impact of Networking on Bank Financing: The Case of Small and Medium-Sized Enterprises in Viet Nam. Entrepreneurship Theory and Practice, 33(4), 867-887. http://dx.doi.org/10.1111/j.1540-6520.2009.00330.x

Le, Venkatesh, S., \& Nguyen, T. V. (2006). Getting bank financing: A study of Vietnamese private firms. Asia Pacific Journal of Management, 23(2), 209-227. http://dx.doi.org/10.1007/s10490-006-7167-8

Malesky, E. J., \& Taussig, M. (2009). Where Is Credit Due? Legal Institutions, Connections, and the Efficiency of Bank Lending in Viet Nam. Journal of Law, Economics, and Organization, 25(2), 535-578. http://dx.doi.org/10.1093/jleo/ewn011

Myers, S. C. (1984). Capital structure puzzle: National Bureau of Economic Research Cambridge, Mass., USA

Nakano, M., \& Nguyen, P. (2011). Do older boards affect firm performance? An empirical analysis based on Japanese firms. An Empirical Analysis Based on Japanese Firms (July 6, 2011).

OECD. (1998). Small businesses, job creation and growth: Facts, obstacles and best practices. Retrieved from

http://www.oecd.org/industry/smesandentrepreneurship/2090740.pdf

Oliner, S. D., \& Rudebusch, G. D. (1992). Sources of the financing hierarchy for business investment. The review of Economics and Statistics, 643-654. http://dx.doi.org/10.2307/2109378

Petersen, M. A., \& Rajan, R. G. (2002). Does distance still matter? The information revolution in small business lending. The Journal of Finance, 57(6), 2533-2570. http://dx.doi.org/10.1111/1540-6261.00505

Rand, J. (2007). Credit constraints and determinants of the cost of capital in Vietnamese manufacturing. Small Business Economics, 29(1), 1-13.

http://dx.doi.org/10.1007/s11187-005-1161-2

Runckel, C., W. (2011). Small and Medium Enterprises (SME) in Viet Nam. [Report]. Business in Asia.

Safavian, M., \& Wimpey, J. (2007). When Do Enterprises Prefer Informal Credit? World Bank Policy Research Working Paper Series, Vol.

Shane, S., \& Cable, D. (2002). Network ties, reputation, and the financing of new ventures. Management Science, 48(3), 364-381. http://dx.doi.org/10.1287/mnsc.48.3.364.7731

Straub, S. (2005). Informal sector: the credit market channel. Journal of Development Economics, 78(2), 299-321. http://dx.doi.org/10.1016/j.jdeveco.2004.09.005

Thanh, V., Cuong, T. T., Dung, B., \& Chieu, T. D. U. C. (2011). Small and Medium Enterprises Access to Finance in Viet Nam. Jakarta: Economic Research Institute for ASEAN and East Asia (ERIA). 


\section{Macrothink}

Journal of Management Research

ISSN 1941-899X 2013, Vol. 5, No. 2

Tsai, K. S. (2004). Imperfect substitutes: The local political economy of informal finance and microfinance in rural China and India. World Development, 32(9), 1487-1507. http://dx.doi.org/10.1016/j.worlddev.2004.06.001

Uchida, H. (2011). What Do Banks Evaluate When They Screen Borrowers? Soft Information, Hard Information and Collateral. Journal of Financial Services Research, 40(1-2), 29-48. http://dx.doi.org/10.1007/s10693-010-0100-9

Yaldiz, E., Altunbas, Yener and Bazzana, Flavio. (2011). Determinants of Informal Credit Use: A Cross Country Study. Midwest Finance Association 2012 Annual Meetings Paper.

\section{Appendix}

Table 1. Some performance indicators of in Viet Nam SMEs

\begin{tabular}{|l|c|c|c|}
\hline \multicolumn{1}{|c|}{ Performance criteria } & $\mathbf{2 0 0 0}$ & $\mathbf{2 0 0 4}$ & $\mathbf{2 0 0 8}$ \\
\hline Number of employees (person) & 236253 & 431942 & 565893 \\
\hline Capital resource at 31/12 (bil.VND) & 18059 & 49346 & 163904 \\
\hline Net turnover (bil.VND) & 71072 & 136156 & 386062 \\
\hline Profit before taxes (bil.VND) & 770 & 1342 & 2189 \\
\hline $\begin{array}{l}\text { Tax and other contributions } \\
\text { to the national budget (bil.VND) }\end{array}$ & 1131 & 2846 & 7940 \\
\hline
\end{tabular}

Source: Authors' calculation from Viet Nam Enterprise Census 2000 - 2008 
Table 2. Summary of main variables

\begin{tabular}{|c|c|c|c|c|}
\hline Variable & Explanation & Mean & SD & $\mathbf{N}$ \\
\hline \multicolumn{5}{|c|}{ Dependent variables } \\
\hline \multirow{3}{*}{ SOURCE } & Using own capital (\%) & 45.011 & 45.929 & 4456 \\
\hline & Borrowing from bank (\%) & 13.962 & 30.613 & 4456 \\
\hline & Borrowing from others (\%) & 41.027 & 47.048 & 4456 \\
\hline \multirow{4}{*}{ CHOICE } & None of informal/formal $(=1)$ & \multirow{3}{*}{2.287} & \multirow{3}{*}{1.143} & \multirow{3}{*}{8110} \\
\hline & Informal source $(=2)$ & & & \\
\hline & Formal source $(=3)$ & & & \\
\hline & Both formal and informal $(=4)$ & & & \\
\hline \multicolumn{5}{|c|}{ Explanatory variables } \\
\hline gender & $1=$ male, 0 otherwise & 0.672913 & 0.469178 & 8111 \\
\hline age & Age of owner/manager & 45.22315 & 10.43081 & 8111 \\
\hline firm_age & Age of firm & 13.14022 & 10.49233 & 8080 \\
\hline road & There is main road leading to the firm & 0.771298 & 0.420023 & 8111 \\
\hline rail & Firm is located near a railway station & 0.365553 & 0.499708 & 8111 \\
\hline ethnic & $1=$ Kinh, 0 otherwise & 0.934402 & 0.247593 & 8110 \\
\hline cp_mem & $\begin{array}{l}\text { Owner/Manager is a member of Communist } \\
\text { party }=1,0 \text { otherwise }\end{array}$ & 0.080385 & 0.271905 & 8111 \\
\hline export & Export $=1,0$ otherwise & 0.054001 & 0.226033 & 8111 \\
\hline acc_book & Firm has accounting book $=1,0$ otherwise & 0.383677 & 0.495354 & 8111 \\
\hline edu_bs & $\begin{array}{l}\text { Owner/Manager basic education } \\
(0=\text { None-4=high school })\end{array}$ & 4.413513 & 0.812592 & 8111 \\
\hline edu_pro & $\begin{array}{lr}\text { Owner/Manager's } \quad \text { professional education } \\
(0=\text { unskilled- } 4=\text { college/university })\end{array}$ & 2.431389 & 1.317883 & 8111 \\
\hline size & Number of laborers at establishment & 19.86081 & 59.10234 & 8111 \\
\hline network_bank & $\begin{array}{l}\text { Number of bank officials the firm frequently } \\
\text { contact with }\end{array}$ & 0.847842 & 1.073351 & 8110 \\
\hline member & Number of business association membership & 0.127237 & 0.435669 & 8103 \\
\hline etp_law & Knowledge about enterprise law & 2.782614 & 1.091325 & 8110 \\
\hline tax_law & Knowledge about tax law & 2.604439 & 1.033121 & 8110 \\
\hline land_ownership & $1=$ has certificate of land use right & 0.566391 & 0.495603 & 8111 \\
\hline infml_loan & Ever access to informal loan $=1,0$ otherwise & 0.5291 & 0.499183 & 8110 \\
\hline bank_loan & Ever access to bank loan $=1,0$ otherwise & 0.379162 & 0.485208 & 8110 \\
\hline own_k & $\begin{array}{l}\text { Using own capital to finance new investment } \\
(\%)\end{array}$ & 45.01116 & 45.92941 & 4456 \\
\hline bank_k & $\begin{array}{l}\text { Using bank capital to finance new investment } \\
(\%)\end{array}$ & 13.96223 & 30.61262 & 4456 \\
\hline otherssource_k & $\begin{array}{l}\text { Using other sources to finance new investment } \\
(\%)\end{array}$ & 41.02661 & 47.04836 & 4456 \\
\hline
\end{tabular}


Table 3. Determinants of Financing Pattern for New Investment Project

\begin{tabular}{|c|c|c|c|c|c|c|c|}
\hline \multirow{2}{*}{\begin{tabular}{|l} 
Variable \\
gender
\end{tabular}} & \multirow{2}{*}{\begin{tabular}{|r|} 
Explaination \\
$1=$ male, 0 otherwise
\end{tabular}} & \multicolumn{2}{|c|}{ Use own capital } & \multicolumn{2}{|c|}{ Borrow from bank } & \multicolumn{2}{|c|}{$\begin{array}{c}\text { Borrow from other } \\
\text { sources }\end{array}$} \\
\hline & & -1.081 & $(1.102)$ & 1.472 & $(0.93)$ & -0.285 & $(0.81)$ \\
\hline lnage & Ln age of owner/manager & -0.270 & $(2.339)$ & 0.952 & $(1.98)$ & -0.365 & $(1.74)$ \\
\hline firm_age & Age of firm & -0.053 & $(0.058)$ & 0.000 & $(0.05)$ & 0.059 & $(0.04)$ \\
\hline road & $\begin{array}{l}\text { There is main road leading to } \\
\text { the firm }\end{array}$ & -2.119 & $(1.286)$ & 0.340 & $(1.09)$ & 1.770 & $(0.93)$ \\
\hline rail & $\begin{array}{l}\text { Firm is located near a railway } \\
\text { station }\end{array}$ & 1.831 & $(1.074)$ & $-3.912 * * *$ & $(0.91)$ & $1.949^{*}$ & $(0.76)$ \\
\hline ethnic & $1=$ Kinh, 0 otherwise & 5.416 & $(3.057)$ & -1.628 & $(2.59)$ & -3.751 & (2.23) \\
\hline cp_mem & $\begin{array}{l}\text { Owner/Manager is a member } \\
\text { of Communist party }\end{array}$ & 0.604 & $(1.755)$ & -0.382 & $(1.49)$ & -0.131 & $(1.28)$ \\
\hline export & Firm has export & $-5.379^{*}$ & $(2.122)$ & -2.415 & $(1.80)$ & $7.655^{* * *}$ & $(1.56)$ \\
\hline acc_book & Firm has accounting book & $-7.743 * * *$ & $(1.690)$ & -0.270 & $(1.43)$ & $7.847 * * *$ & $(1.22)$ \\
\hline network_bank & $\begin{array}{l}\text { Number of bank officials the } \\
\text { firm frequently contact with }\end{array}$ & $-9.355 * * *$ & $(0.473)$ & $7.118 * * *$ & $(0.40)$ & $1.994 * * *$ & $(0.34)$ \\
\hline member & $\begin{array}{l}\text { Number of business } \\
\text { association membership }\end{array}$ & -1.291 & $(1.082)$ & -0.922 & $(0.92)$ & $2.047 *$ & $(0.80)$ \\
\hline etp_law & $\begin{array}{l}\text { Knowledge about enterprise } \\
\text { law }\end{array}$ & $2.726 * * *$ & $(0.762)$ & $-1.63^{*}$ & $(0.64)$ & $-1.079^{*}$ & $(0.54)$ \\
\hline tax_law & Knowledge about tax law & -1.014 & $(0.730)$ & $1.88 * *$ & $(0.62)$ & -0.856 & $(0.52)$ \\
\hline Inprofit & Ln profit & $8.730 * * *$ & $(0.178)$ & $3.25^{* * *}$ & $(0.15)$ & $-12.10 * * *$ & $(0.13)$ \\
\hline edu_bs2 & Not finished primary & -11.367 & $(11.246)$ & 12.705 & $(9.52)$ & -1.123 & $(8.01)$ \\
\hline edu_bs3 & Finished primary & -12.253 & $(10.909)$ & 8.920 & $(9.23)$ & 3.652 & $(7.78)$ \\
\hline edu_bs4 & Finished lower secondary & -8.428 & (10.777) & 6.136 & $(9.12)$ & 2.460 & (7.69) \\
\hline edu_bs5 & Finished upper Secondary & -7.302 & $(10.789)$ & 4.740 & $(9.13)$ & 2.752 & $(7.70)$ \\
\hline edu_pro1 & Unskilled & 1.847 & $(1.546)$ & 1.511 & $(1.31)$ & $-3.398 * *$ & $(1.11)$ \\
\hline edu_pro2 & Elementary worker & 3.132 & $(1.614)$ & 2.134 & $(1.37)$ & $-5.386 * * *$ & $(1.14)$ \\
\hline edu_pro4 & $\begin{array}{l}\text { Technical worker with } \\
\text { certificate }\end{array}$ & -0.511 & $(1.653)$ & 1.260 & $(1.40)$ & -0.648 & $(1.18)$ \\
\hline
\end{tabular}




\begin{tabular}{|c|c|c|c|c|c|c|c|}
\hline edu_pro5 & $\begin{array}{l}\text { College/university/post-gradua } \\
\text { te }\end{array}$ & $-6.492 * *$ & $(2.113)$ & -1.998 & $(1.79)$ & $8.46 * * *$ & $(1.51)$ \\
\hline ownership1 & Household business & 27.293 & $(18.640)$ & -16.550 & $(15.78)$ & -12.030 & $(13.38)$ \\
\hline ownership2 & Private/sole proprietorship & 27.035 & $(18.660)$ & -18.823 & $(15.79)$ & -9.443 & $(13.39)$ \\
\hline ownership3 & Partnership & 31.775 & $(19.947)$ & -21.151 & $(16.88)$ & -11.087 & $(14.34)$ \\
\hline ownership4 & Collective/Cooperative & 25.093 & $(18.783)$ & -20.368 & $(15.90)$ & -5.910 & $(13.49)$ \\
\hline ownership5 & Limited liability company & 21.747 & $(18.639)$ & -18.270 & $(15.78)$ & -4.252 & $(13.38)$ \\
\hline ownership6 & Joint stock company with state & 3.086 & $(20.633)$ & -7.422 & $(17.47)$ & 4.077 & $(14.83)$ \\
\hline ownership7 & $\begin{array}{l}\text { Joint stock company without } \\
\text { state }\end{array}$ & 16.531 & $(18.808)$ & -16.379 & $(15.92)$ & -0.494 & $(13.51)$ \\
\hline region 1 & Hanoi & $7.126 * *$ & $(2.696)$ & $-12.21 * * *$ & $(2.28)$ & $4.862 *$ & $(2.06)$ \\
\hline region2 & PhuTho & $-5.816^{*}$ & $(2.644)$ & $8.825 * * *$ & $(2.24)$ & -3.245 & $(2.03)$ \\
\hline region3 & Ha Tay & $9.685 * * *$ & $(2.579)$ & $-12.47 * * *$ & $(2.18)$ & 2.358 & (1.98) \\
\hline region4 & HaiPhong & -5.143 & $(2.841)$ & $-5.471 *$ & $(2.40)$ & $10.807 * * *$ & $(2.17)$ \\
\hline region5 & Nghe An & $10.909 * * *$ & $(2.591)$ & $-6.366 * *$ & $(2.19)$ & $-4.530 *$ & (1.98) \\
\hline region6 & Quang Nam & 4.995 & $(2.875)$ & 0.441 & $(2.43)$ & $-5.713 * *$ & $(2.21)$ \\
\hline region7 & KhanhHoa & -4.619 & $(3.296)$ & -0.974 & $(2.79)$ & $5.742 *$ & $(2.52)$ \\
\hline region8 & Lam Dong & -3.030 & $(3.604)$ & 2.154 & $(3.05)$ & 0.293 & $(2.75)$ \\
\hline region9 & Hochiminh city & 1.327 & $(2.619)$ & $-7.926 * * *$ & $(2.22)$ & $6.472 * *$ & (1.99) \\
\hline land_ownershi & $\begin{array}{l}\text { Firm has certificate of land use } \\
\text { right }\end{array}$ & 1.925 & $(1.053)$ & 0.145 & $(0.89)$ & $-1.841^{*}$ & $(0.77)$ \\
\hline Constant & & $-50.979 *$ & $(23.631)$ & -10.261 & $(20.00)$ & $\begin{array}{l}162.199 * * \\
*\end{array}$ & (17.03) \\
\hline R-square & & 0.514 & & 0.229 & & 0.760 & \\
\hline Number of obs & & 4344 & & 4344 & & 4344 & \\
\hline
\end{tabular}

Legend: ${ }^{*} \mathrm{p}<0.05 ; * * \mathrm{p}<0.01 ; * * * \mathrm{p}<0.001$.

Standard errors in parenthesis 
Table 4. Determinants of access to formal/informal finance

\begin{tabular}{|c|c|c|c|c|c|c|}
\hline Variable & Informal & ource & Formal s & ource & Both informal & source \\
\hline gender & 0.094 & $(0.07)$ & 0.138 & $(0.09)$ & 0.105 & $(0.08)$ \\
\hline Inage & $-0.55 * * *$ & $(0.15)$ & $0.53 * * *$ & $(0.19)$ & $-0.830 * * *$ & $(0.18)$ \\
\hline firm_age & -0.004 & $(0.00)$ & $-0.011 * *$ & $(0.00)$ & $-0.01 * *$ & $(0.00)$ \\
\hline road & 0.106 & $(0.08)$ & $-0.187 * *$ & $(0.10)$ & 0.055 & $(0.10)$ \\
\hline rail & $0.345^{* * *}$ & $(0.07)$ & $-0.57 * * *$ & $(0.10)$ & $0.208^{* *}$ & $(0.09)$ \\
\hline ethnic & 0.055 & $(0.13)$ & $0.395^{* *}$ & $(0.20)$ & $0.764 * * *$ & $(0.20)$ \\
\hline cp_mem & -0.103 & $(0.13)$ & 0.035 & $(0.16)$ & -0.021 & $(0.15)$ \\
\hline export & -0.023 & $(0.18)$ & 0.04 & $(0.21)$ & 0.183 & $(0.19)$ \\
\hline acc_book & 0.037 & $(0.10)$ & 0.133 & $(0.15)$ & $0.408 * * *$ & $(0.14)$ \\
\hline network_bank & $1.038^{* * *}$ & $(0.06)$ & $1.876^{* * *}$ & $(0.06)$ & $1.993 * * *$ & $(0.06)$ \\
\hline member & 0.113 & 0.10 & $0.3^{* *}$ & $(0.11)$ & $0.249^{* *}$ & $(0.11)$ \\
\hline tax_law & $0.069 * *$ & $(0.04)$ & 0.07 & $(0.06)$ & $0.055^{*}$ & $(0.06)$ \\
\hline Inprofit & $-0.08 * * *$ & $(0.01)$ & $0.138 * * *$ & $(0.02)$ & 0.014 & $(0.01)$ \\
\hline edu_bs1 & -0.155 & $(0.37)$ & -0.73 & $(0.79)$ & -0.261 & $(0.61)$ \\
\hline edu_bs2 & -0.03 & $(0.17)$ & 0.206 & $(0.24)$ & -0.043 & $(0.64)$ \\
\hline edu_bs3 & 0.076 & $(0.12)$ & 0.109 & $(0.16)$ & -0.247 & $(0.62)$ \\
\hline edu_bs5 & -0.041 & $(0.08)$ & 0.2 & $(0.11)$ & -0.298 & $(0.61)$ \\
\hline edu_pro1 & -0.15 & $(0.09)$ & 0.042 & $(0.13)$ & -0.015 & $(0.12)$ \\
\hline edu_pro2 & $-0.260^{* *}$ & $(0.10)$ & -0.144 & $(0.14)$ & -0.192 & $(0.13)$ \\
\hline edu_pro4 & $-0.222 * *$ & $(0.11)$ & 0.076 & $(0.15)$ & -0.133 & $(0.14)$ \\
\hline edu_pro5 & -0.241 & $(0.16)$ & 0.051 & $(0.23)$ & 0.197 & $(0.18)$ \\
\hline ownership2 & -0.003 & $(0.13)$ & 0.234 & $(0.34)$ & 0.042 & $(0.20)$ \\
\hline ownership3 & -0.547 & $(0.56)$ & 1.38 & $(0.46)$ & $1.172 *$ & $(0.13)$ \\
\hline ownership4 & -0.193 & $(0.21)$ & -0.467 & $(0.29)$ & $-1.71^{*}$ & $(0.29)$ \\
\hline ownership5 & 0.142 & $(0.06)$ & 0.127 & $(0.34)$ & $0.694 * * *$ & $(0.23)$ \\
\hline ownership6 & -1.327 & $(0.39)$ & -0.994 & $(0.91)$ & $0 . .57 * * *$ & $(0.86)$ \\
\hline ownership7 & -0.169 & $(0.09)$ & 0.513 & $(0.37)$ & $0.466^{* * *}$ & $(0.53)$ \\
\hline region1 & $1.015^{* * *}$ & $(0.19)$ & -0.121 & $(0.25)$ & $0.467^{*}$ & $(0.23)$ \\
\hline region2 & 0.214 & $(0.19)$ & $1.130^{* * *}$ & $(0.23)$ & $1.091^{* * *}$ & $(0.22)$ \\
\hline region3 & -0.179 & $(0.19)$ & $0.770 * * *$ & $(0.21)$ & $0.830 * * *$ & $(0.21)$ \\
\hline region4 & $0.433 * *$ & $(0.20)$ & 0.364 & $(0.25)$ & -0.06 & $(0.24)$ \\
\hline region5 & $0.649 * * *$ & $(0.18)$ & $0.744 * * *$ & $(0.22)$ & $0.783^{* * *}$ & $(0.21)$ \\
\hline region6 & -0.232 & $(0.21)$ & $0.765^{* * *}$ & $(0.24)$ & $0.568 * *$ & $(0.23)$ \\
\hline region7 & $1.055^{* * *}$ & $(0.23)$ & 0.291 & $(0.31)$ & $0.809 * * *$ & $(0.28)$ \\
\hline region8 & $0.667 * * *$ & $(0.23)$ & $0.772 * * *$ & $(0.28)$ & $0.687^{* *}$ & $(0.29)$ \\
\hline region9 & $0.708^{* * *}$ & $(0.18)$ & 0.253 & $(0.22)$ & $0.592 * * *$ & $(0.21)$ \\
\hline land_ownership & $-0.146^{* *}$ & $(0.07)$ & -0.052 & $(0.09)$ & $-0.154 *$ & $(0.08)$ \\
\hline
\end{tabular}




\begin{tabular}{|l|l|c|c|c|c|c|}
\hline Constant & $1.613^{*}$ & $(0.61)$ & -1.716 & $(0.75)$ & -0.312 & 0.00 \\
\hline Pseudo-R square (\%) & \multicolumn{5}{|c|}{20.05} \\
\hline Number of obs & 7907 & & 7907 & & 7907 & \\
\hline
\end{tabular}

Legend: ${ }^{*} \mathrm{p}<0.05 ; * * \mathrm{p}<0.01 ; * * * \mathrm{p}<0.001$

Standard errors in parenthesis

\section{Copyright Disclaimer}

Copyright reserved by the author(s).

This article is an open-access article distributed under the terms and conditions of the Creative Commons Attribution license (http://creativecommons.org/licenses/by/3.0/). 